\title{
AS TRÊS IDENTIDADES DO DISCURSO AUTOBIOGRÁFICO: REFLEXÕES SOBRE A OBRA DE PEDRO NAVA
}

\section{THREE IDENTITIES OF THE AUTOBIOGRAPHICAL DISCOURSE: SOME REFLECTIONS ON PEDRO NAVA'S WORK}

Mariana Luz Pessoa de Barros USP - Universidade de São Paulo

\begin{abstract}
RESUMO: Os diários, as cartas, os memoriais acadêmicos, os romances autobiográficos são gêneros que realizam o discurso autobiográfico, cuja marca central é, além da temática da "minha vida" - o "eu" é o centro do discurso -, a produção do efeito de identidade entre o enunciador e o narrador; o narrador e o protagonista; o protagonista e o enunciador. Ao examinar os livros que compõem as Memórias de Pedro Nava, notamos que, a partir da segunda metade de Galo-das-trevas (quinto volume), esse triplo efeito de identidade não se realiza por completo. Por meio de uma análise centrada na sintaxe e na semântica discursiva, procuramos desvendar os mecanismos labirínticos que rompem essa coerção dos gêneros autobiográficos e seus efeitos de sentido.
\end{abstract}

PALAVRAS-CHAVE: Semiótica Discursiva; Identidade; Autobiografia; Pedro Nava, Galo-dastrevas.

\begin{abstract}
The diaries, letters, academic autobiographies, autobiographical novels are all genres that perform autobiographical discourse. Its key feature is not only the theme of "my life" the "I" being the center of the discourse - but also the production of the identity effect between: the enunciator and the narrator, the narrator and the protagonist, the protagonist and the enunciator. The study of the books that make up the Pedro Nava's Memories shows that, from the second half of Galo-das-trevas (the fifth volume), the triple identity effect is not completely achieved. By analyzing the discursive syntax and semantics, this paper discusses the labyrinthine mechanisms that break the constraints in the autobiographical genres and their effects of sense.
\end{abstract}

KEYWORDS: Discursive Semiotics; Identity; Autobiography; Pedro Nava; Galo-das-trevas.

"Eu sou um pobre homem do Caminho Novo das Minas dos Matos Gerais" (2000, p. 5), assim começam as extensas Memórias de Pedro Nava, talvez a obra autobiográfica mais festejada da literatura brasileira. Aguiar (1998, p.13-14) ressalta o impacto que teve sua publicação:

Ao lançar suas Memórias, Nava logo se tornou um best-seller. A cada volume publicado, seu nome ia para a lista de mais vendidos. Certamente, seu modo de reconstruir o tempo, num estilo exuberante, refinado, divertido e por demais envolvente, foi decisivo para o sucesso da obra junto ao público e também à crítica. 
Para o crítico, Nava vem preencher um lugar deixado vago na tradição do memorialismo brasileiro: "É como se o próprio gênero tivesse se reservado para ele, à espera do seu melhor praticante" (AGUIAR, 1998, p. 16). O autor, que já beirava os setenta anos e que pouco havia publicado na esfera literária - alguns poemas e crônicas -, lança ao longo de pouco mais de uma década seis volumes de memórias, Baú de ossos (2000 [1972]), Balão cativo (2000 [1973]), Chão de ferro (2001 [1976]), Beira-mar (2003 [1978]), Galo-das-trevas (2003 [1981]) e O círio perfeito (2004 [1983]), consagrando-se como escritor. O sétimo livro, Cera das almas (2006), publicado postumamente, teve sua redação interrompida pelo suicídio do autor em maio de $1984^{1}$.

Nossa análise terá como centro o quinto volume - Galo-das-trevas - das Memórias, pelas peculiaridades que apresenta em relação ao discurso autobiográfico. Os demais livros serão trazidos justamente para evidenciar o que essa obra possui de singular com relação à constituição sintática e semântica do enunciador, do narrador e do protagonista, o que irá ressoar em todo o livro e talvez na totalidade da memorialística do autor.

Galo-das-trevas encontra-se dividido em duas partes. A primeira, "Negro", cujo capítulo único se intitula "Jardim da Glória à Beira-Mar plantado", constitui um momento de exceção na obra de Nava. Vamos reencontrar o tempo e o espaço da narração, pois o narrador, um homem velho e amargurado, fala de seu presente a partir do apartamento no bairro da Glória (Rio de Janeiro). Relata os encontros com seus mortos numa noite de insônia, seus passeios pelo Rio, lugar impregnado de lembranças, mas que já não é mais o mesmo. No final dessa parte, ele anuncia que passará a narrar as memórias daquele que diz ser seu alter ego, José Egon Barros da Cunha. Na segunda parte, "O branco e o marrom", formada pelos capítulos "Santo Antônio do Desterro" e "Belorizonte Belo", Egon se torna então personagem central. Ele já havia aparecido nos volumes anteriores das Memórias, sendo apresentado como um primo de Pedro Nava, um sósia, e mesmo um alter ego. O primeiro capítulo dessa segunda parte narra a expedição para Caetés, a verdadeira estreia como médico do Dr. Egon, seu "batismo", como diz o narrador. Em seguida, o médico parte para Santo Antônio do Desterro, sua cidade natal, que corresponderia a Juiz de Fora, de onde é Pedro Nava. A cidade não o acolhe como esperava e o jovem decide retornar a Belo Horizonte um ano e meio depois de sua chegada. O segundo capítulo é dedicado ao período em Belo Horizonte, onde Egon encontra certa estabilidade. O livro termina com os tiros anunciando a Revolução de 30.

\section{O discurso autobiográfico}

Os diários, as cartas, os memoriais acadêmicos, os romances autobiográficos são gêneros que realizam o discurso autobiográfico, cuja marca central é, além da temática da "minha vida" - o "eu" é o centro do discurso -, a produção do efeito de identidade entre o enunciador e o narrador; o narrador e o protagonista (ator central do narrado); o protagonista e o enunciador. O papel dessa tripla relação de identidade nos gêneros autobiográficos vem sendo debatido por diversos pesquisadores.

Segundo Lejeune $(1996,2005)$, a relação de identidade entre autor e narrador, narrador e personagem central, personagem central e autor é o que fundamenta o que chamou de pacto autobiográfico: uma espécie de contrato estabelecido entre o autor e o leitor, ou

\footnotetext{
${ }^{1}$ Nas citações, os livros serão doravante designados por suas iniciais.
} 
ainda um ato de linguagem, um performativo, uma promessa. Em oposição ao pacto romanesco, trata-se de um compromisso assumido pelo autor de contar sua vida num espírito de verdade, o que acarreta uma forma de leitura específica. Lejeune $(1996,2005)$ afirma ainda que o pacto autobiográfico não diz respeito à correspondência ponto por ponto do texto à vida extralinguística, porém não nega que seria legítimo verificar a existência de uma adequação em nível mais amplo, pois, para ele, aquele que escreve uma obra autobiográfica compromete-se definitivamente com a verdade. O teórico relativiza em parte essa visão quando trata de obras autobiográficas mais literárias, todavia sua concepção primordial é de que a autobiografia institui um pacto referencial de leitura, como o discurso histórico ou científico, posição que não será assumida neste trabalho.

Genette (1991, p. 83) também abordou a questão das identidades, entendendo a autobiografia como um discurso homodiegético não ficcional:

$$
A=\text { autor }, P=\text { personagem }, N=\text { narrador }
$$

$\mathrm{A}=\mathrm{P}, \mathrm{P}=\mathrm{N}, \mathrm{N}=\mathrm{A} \rightarrow$ autobiografia (discurso homodiegético não ficcional)

$\mathrm{A} \neq \mathrm{P}, \mathrm{P} \neq \mathrm{N}, \mathrm{N}=\mathrm{A} \rightarrow$ biografia (discurso heterodiegético não ficcional)

$\mathrm{A} \neq \mathrm{P}, \mathrm{P}=\mathrm{N}, \mathrm{N} \neq \mathrm{A} \rightarrow$ ficção homodiegética

$A=P, P \neq N, N \neq A \rightarrow$ autobiografia heterodiegética

$\mathrm{A} \neq \mathrm{P}, \mathrm{P} \neq \mathrm{N}, \mathrm{N} \neq \mathrm{A} \rightarrow$ ficção heterodiegética

Com base nesses autores, adotamos a noção de tripla identidade, mas como efeito que cria a ilusão de que a vida narrada pertence ao enunciador, pois, como afirma Parret (1988): “"Minha vida' é uma narrativa, um discurso: que esta vida seja minha não é senão um efeito de discurso, um simulacro discursivo" (p. 43; tradução nossa) ${ }^{2}$.

$\mathrm{O}$ efeito de identidade entre narrador e protagonista é produzido, geralmente, pelo emprego do pronome $e u$, ou seja, por uma debreagem enunciativa do enunciado: "quando o narrador se identifica com uma das personagens, naquilo que concerne ao enunciado enunciado, ou seja, ao eu actante da narrativa" (FIORIN, 1996, p. 117). Já o efeito de identidade entre enunciador e protagonista pode realizar-se pela onomástica, que concretiza semanticamente num mesmo antropônimo o ator da enunciação e o ator do narrado. Lejeune (1996) chama a atenção para a coincidência do nome do autor, na capa do livro, e o da personagem.

$\mathrm{O}$ efeito de identidade entre narrador e enunciador resulta das identidades anteriores, podendo ser fortalecido pelo fato de o narrador apresentar-se, muitas vezes, como o autor da obra. É o que chamamos na semiótica de embreagem:

Ao contrário de debreagem, que é a expulsão, da instância da enunciação, de termos categóricos que servem de suporte ao enunciado, denomina-se embreagem o efeito de retorno à enunciação, produzido pela suspensão da oposição entre certos termos da categoria da pessoa e/ou do espaço e/ou do tempo, bem como pela denegação da instância da enunciação. Toda embreagem pressupõe, portanto, uma operação de debreagem que lhe é logicamente anterior (GREIMAS; COURTÈS, 2008, p. 159-160).

\footnotetext{
2 “"Ma vie' est un récit, un discours: que cette vie soit à moi n'est qu'un effet de discours, un simulacre discursif".
} 
Nesse caso, temos um tipo de embreagem que confunde os níveis do narrador e do enunciador, instância pressuposta, criando a aproximação entre eles (FIORIN, 1996, p. 122-123). O narrador, instalado no enunciado sempre como um não-eu em relação à enunciação, é apresentado como se fosse o enunciador ${ }^{3}$. Isso aparece com frequência na abertura das obras, especialmente depois de Rousseau, que inicia suas Confissões (1933) com um pequeno texto assinado, no qual justifica, então, não apenas o que levou o narrador a contar sua história, mas os motivos que fizeram com que o enunciador a escrevesse e publicasse.

É o que encontramos também na obra de José de Alencar, Como e por que sou romancista, que data de 1873 e foi publicada postumamente em $1893^{4}$.

\section{Meu amigo}

Na conversa que tivemos, há dias, exprimiu V. o desejo de colher acerca da minha peregrinação literária alguns pormenores dessa parte íntima de nossa existência, que geralmente fica à sombra, no regaço da família ou na reserva da amizade.[...] Seria esse o livro dos meus livros. [...] Enquanto não vem ao lume do papel, que para o da imprensa ainda é cedo, essa obra futura, quero em sua intenção fazer o rascunho de um capítulo.

Será daquele, onde se referem as circunstâncias, a que atribuo a predileção de meu espírito pela forma literária do romance (1955, p. 5-7).

Outras estratégias discursivas podem contribuir para reforçar as identidades próprias ao gênero, como a explicitação no título ou subtítulo do fato de tratar-se de uma obra autobiográfica (memórias, história da minha vida, lembranças, etc.) (LEJEUNE, 1996). Isso cria no enunciatário a expectativa, que pode ser confirmada ou não, de convergência das três instâncias mencionadas.

\section{Galo-das-trevas: a diluição das identidades}

Do primeiro (Baú de ossos) até o quarto volume (Beira-mar) da obra de Pedro Nava, reconhecemos, sem maiores dificuldades, esse triplo efeito de identidade característico das obras autobiográficas. A classificação genérica da obra - "memórias" -, que aparece na capa, já sugere para o enunciatário a identificação entre as instâncias mencionadas.

$\mathrm{O}$ efeito de identidade entre $\mathrm{o}$ ator do narrado e o enunciador é garantido, principalmente, pelo nome, Pedro Nava, reconhecido na capa como autor e, no interior da obra, como o ator do narrado que protagoniza as Memórias. Em Baú de ossos, na primeira de suas duas dedicatórias, lemos 5 :

\footnotetext{
${ }^{3}$ É preciso lembrar que a debreagem, concernente à instauração de pessoas, tempos e espaços no enunciado, consiste num primeiro momento "[...] em disjungir do sujeito, do espaço e do tempo da enunciação e em projetar no enunciado um não-eu, um não-aqui e um não-agora" (FIORIN, 1996, p. 43).

${ }^{4}$ Esse livro pode ser considerado um dos precursores da literatura memorialista no Brasil, pois, conforme mostra Fávero (1999, p. 31), traz inúmeros temas retomados mais tarde pelas obras autobiográficas produzidas em nosso país. Também Castelo (1999, p. 385) aponta José de Alencar como um dos autores que marcam o surgimento da literatura memorialista no Brasil, sendo os outros Joaquim Nabuco e Graça Aranha, que escreveram no final do século XIX. Seria preciso ainda pensar no papel dos cronistas dentro de uma história dos gêneros autobiográficos no Brasil.

${ }^{5} \mathrm{O}$ livro apresenta duas dedicatórias. Na primeira, o autor homenageia alguns amigos e, principalmente, os parentes falecidos e na segunda, seus amigos e sua esposa, Antonieta Penido, apresentada pelo apelido, Nieta.

Disponível em: http://seer.fclar.unesp.br/casa
} 
CASA, Vol.10 n.2, dezembro de 2012

À memória de
PEDRO DA SILVA NAVA e
ANA CÂNDIDA PAMPLONA NAVA FEIJÓ
meus avós

JOSÉ NAVA $e$ DIVA JAGUARIBE NAVA, meus pais;

ALICE NAVA SALLES $e$ ANTÔNIO SALLES

meus tios;

JOSÉ HIPÓLITO NAVA RIBEIRO

meu sobrinho;

ALICE DE LUNA FREIRA

minha prima;

GASTÃO CRULS, JOAQUIM NUNES COUTINHO CAVALCANTI $e$ RODRIGO DE MELO FRANCO DE ANDRADE, meus amigos.

P R O F U N D A M E N T E

Além de já introduzir o enunciatário no mundo dos mortos, que vai ocupar boa parte das Memórias, a dedicatória também reforça a identidade entre o enunciador, ao qual se atribui a responsabilidade de escrevê-la, e o ator do narrado. O nome dos familiares ("JOSÉ NAVA $e$ DIVA JAGUARIBE NAVA"), acompanhado da relação de parentesco ("meus pais") com esse enunciador, permite que o enunciatário, ao longo da leitura, reconheça esses mesmos atores como parentes e amigos do Pedro Nava, Pedro ou Pedrinho, como é chamado o ator do narrado.

Outros recursos vêm reforçar tal identificação, como o relato da produção de obras por parte do ator do narrado, que o enunciatário identifica como sendo da autoria de Pedro Nava, enunciador. É o caso de seu conhecido poema "O defunto", publicado mais tarde na Antologia de poetas bissextos brasileiros contemporâneos, organizada em 1946 por Manuel Bandeira: "Foi nesse sótão que mais tarde, a 23 de julho de 1938, dum jato, rejeitei de mim 'O defunto"' (GT, p. 452).

Além disso, a interdiscursividade também corrobora a produção da identificação, permitindo ao enunciatário, com seu conhecimento a respeito do autor, originado da leitura de biografias, reportagens e notícias, estabelecer certa correspondência entre a vida narrada nas Memórias e aquela que aparece nos outros discursos. Salientamos que a interdiscursividade apenas pode fortalecer um efeito localizável no interior da obra, a não ser que se queira ler qualquer texto como autobiográfico, sem levar em conta o que as marcas discursivas sugerem. É nesse sentido que afirmamos que a interdiscursividade vai tornar ainda mais eficaz o efeito de identidade entre enunciador e ator do narrado, mas ela não será neste trabalho tomada como critério único para o estabelecimento desse efeito.

A identificação entre o enunciador e o narrador, em Nava, realiza-se por meio da embreagem de pessoa, que confunde os níveis do enunciador e do narrador. Isso faz com que o enunciatário atribua a responsabilidade pelo que é dito tanto ao narrador quanto ao 
enunciador. Conforme já foi comentado, a presença de uma espécie de prólogo assinado é muitas vezes responsável pela produção de semelhante efeito. Na obra de Pedro Nava, não há esse "prólogo". Entretanto, em toda a primeira parte de Galo-das-trevas, além de explicar a aparição de Egon, o alter ego, o narrador justifica a escritura das Memórias. Nessa parte, que se destaca do todo da obra, encontramos o narrador falando, predominantemente, do aqui e do agora da narração. Para o espaço temos seu apartamento no bairro da Glória, no Rio de Janeiro: "Estou escrevendo no meu escritório, olhando lá fora o dia molhado, frio e gris que cobre o Aterro (GT, p. 5)". Para o tempo, temos como data inicial o dia 5 de junho de 1978: "É o que penso no dia em que completo setenta e cinco anos de vida e começo este meu quinto volume de memórias" (GT, p. 5). Segundo Aguiar (1998), esse capítulo é de fundamental importância para o leitor da obra literária de Nava, pois constitui uma interrupção do fio narrativo que vinha se desenrolando, além de ser também uma parte de transição (entre narradores e entre protagonistas, conforme veremos adiante):

[...] em "Jardim da Glória" o tempo é puxado para o presente, para o ato de sua escritura, compreendendo, sem dúvida, a passagem de maior subjetividade das Memórias. O capítulo é uma espécie de ponto de chegada, a partir do qual o caminho se bifurca novamente, abrindo espaço para a continuação da narrativa, que já não será exatamente a mesma. No "Jardim da Glória" se dá o encontro do eu que narra com o escritor. É, portanto, o primeiro grande momento de confissão, explícita, por assim dizer, das Memórias (AGUIAR, 1998, p. 47).

Assim, essa parte pode ser lida como uma grande embreagem actancial, em que narrador e enunciador surgem sobrepostos. Ao longo da obra, encontramos outras passagens do mesmo tipo que merecem atenção, como quando o narrador, comentando um dos filmes assistidos pelo ator do narrado Egon, detém-se no recurso cinematográfico do close-up e diz já ter tratado do tema em livros anteriores: "Já discuti a questão da descoberta do close-up em livro anterior" (GT, p. 200). Podemos mencionar ainda o final de Galo-das-trevas, quando é anunciada a publicação do próximo volume das Memórias. Nesses dois casos, o narrador se apresenta como o autor dos livros.

Rio de Janeiro, Glória, 5 de junho de 1978 - 19 de outubro de 1980.

\begin{tabular}{c} 
Gostou de MEMÓRIAS / 5? \\
Pois aguarde para breve MEMÓRIAS / 6 e a segunda \\
parte deste livro designada: \\
O CÍRIO PERFEITO \\
Galo-das-Trevas / 2 \\
\hline
\end{tabular}

(GT, p. 441)

O efeito de identificação entre o narrador e o enunciador pode ser fortalecido pela debreagem enunciativa da enunciação: "quando os actantes da enunciação estão projetados no enunciado" (FIORIN, 1996, p. 117). Tal procedimento é reconhecido por meio da leitura das marcas de primeira pessoa (do singular ou do plural) ou de segunda, como se nota nas primeiras palavras de Baú de ossos, quando o narrador indica suas origens: "Eu sou um pobre homem do Caminho Novo das Minas dos Matos Gerais" (BO, p. 5). A explicitação do narratário é menos frequente. "Pensam que acabou?" (GT, p. 314), pergunta o narrador no meio de uma extensa descrição da rotina de Dona Diva Jaguaribe Nava (mãe de Pedro Nava). 
As marcas enunciativas não garantem a identificação entre enunciador e narrador, mas reforçam-na. Afinal, mesmo um narrador que fala explicitamente em primeira pessoa pode ser construído de forma a diferenciar-se do enunciador. Há inúmeros exemplos em nossa literatura, sendo um dos mais célebres talvez o narrador de Dom Casmurro (2008), de Machado de Assis, obra em que o enunciatário reconhece Dom Casmurro como narrador e não Machado de Assis, embora tal narrador seja projetado por meio de uma debreagem enunciativa da enunciação.

$\mathrm{O}$ efeito de identidade entre o narrador e o ator do narrado pode ser criado por diferentes recursos, mas em Pedro Nava prevalece a utilização da debreagem enunciativa do enunciado (ator do narrado é um eu) ${ }^{6}$. É o que se verifica no momento em que o narrador descreve os passeios feitos com tio Salles num tempo passado, quando ainda era um menino:

\begin{abstract}
Ainda com tio Salles subi um dia as ladeiras da Rua do Morro, onde morava não sei mais que amigo seu. Enquanto ele parava, no alto, para olhar a vista escampa e larga que dali se descortina - Santa Teresa, o Corcovado e a Tijuca levantando a cara e o nariz pico - eu atentei num pano de muro branco todo cheio de inscrições e desenhos pornográficos. Esse gênero de criação plástica é sempre levado a efeito com a pressa inspirada aos autores pelo medo de um flagrante e a pressa obriga-os a sínteses essenciais, às vezes tão fabulosas que só podem ser comparadas a certos close-ups, relances e gags achados pela suscetibilidade de um cinegrafista de gênio. Tal era o esboço que vi - que guardei de memória, como coisa perturbadora, posto que então incompreensível (BO, p. 369).
\end{abstract}

Nesse fragmento, é possível identificar o eu do narrado, que aparece em "subi" ou "eu atentei" e o eu da narração, que reconhecemos em "não sei". Se os tempos diferenciam o narrador - instaurado no presente da narração - do protagonista - instaurado no passado do narrado -, o pronome pessoal os identifica (STAROBINSKI, 1970, p. 261 262). É preciso dizer ainda que os diferentes procedimentos para a criação dos efeitos de identidade no discurso autobiográfico fortalecem uns aos outros.

A partir de Galo-das-trevas, essa questão das identidades torna-se ainda mais complexa. Conforme já mostramos, o livro está dividido em duas partes: "Negro" e "O branco e o marrom". Na primeira, em que o narrador trata de seu presente ao longo de uma interminável noite que se aprofunda no tempo da memória, reconhecemos a identificação entre enunciador, narrador e ator do narrado, de que tratamos.

"Negro"

- Enunciador: Pedro Nava

- Narrador 1: Pedro Nava (debreagem enunciativa da enunciação - eu)

- Protagonista: Pedro Nava (debreagem enunciativa do enunciado - eu)

É na página 100 de Galo-das-trevas, ainda nessa primeira parte, que o narrador fala sobre o dia em que, logo depois do café, recebeu um embrulho de seu primo Egon, já apresentado em volumes anteriores. Em Galo-das-trevas, o primo é descrito como "sósia, primo, amigo de infância, colégio, faculdade, vida, profissão afora" (GT, p. 79). Egon, ou

\footnotetext{
${ }^{6} \mathrm{O}$ caso de Galo-das-trevas e de $O$ círio perfeito, obras em que o narrador passa a relatar a vida de Egon, será considerado mais adiante.
} 
Doutor José Egon Barros da Cunha, é mostrado como o primo inseparável de Pedro Nava: "mineiro de Santo Antônio do Desterro - outrora Vila Nova d'El-Rey de Santo Antônio do Desterro no Mato Grosso das Minas - nos dias dagora Santo Antônio do Desterro ou só Desterro" (GT, p. 79).

Segundo o relato, o embrulho trazia cinco pastas de cartolina e uma carta, em que Egon explicava que pretendia "desaparecer da vida social, na tolice como ela é entendida hoje" (GT, p. 101). Mudaria para um asilo, onde não desejava ser incomodado até a morte. Deixava para seu primo, Pedro Nava, manuscritos, fotos e documentos: suas memórias. É esse rico material que o narrador afirma constituir a base da história que tem início na segunda parte do livro.

Assim termina o trecho intitulado "Negro". Em "O branco e o marrom", começa, então, o relato que teria sido feito a partir dos manuscritos de Egon. Logo nas primeiras páginas, notamos uma mudança com relação ao narrador.

Para adiantar um pouco o caso, vamos contar que vários dias depois, voltando da zona tifenta, o Egon fora à casa da sua paciente (GT, p. 121, grifos nossos).

Mas... deixemos de conversa fiada e voltemos aos dois amigos (GT, p. 201, grifos nossos).

Já descrevemos seu aspecto físico mas devemos voltar às qualidades morais que o completavam como a um ser absolutamente excepcional (GT, p. 297, grifos nossos).

O narrador que se utiliza sempre da primeira pessoa do singular (narrador 1) dá lugar, a partir da página 103 de Galo-das-trevas, a um segundo narrador (narrador 2), que se utiliza da primeira pessoa do plural. O narrador 1, responsável por passar a palavra a esse segundo narrador, não desaparece por completo em "O branco e o marrom". Salvo engano, ele aparece duas vezes no corpo do texto da parte 2 de Galo-das-trevas. Além disso, é o responsável pela organização do narrado e é a voz dele que reconhecemos nas notas:

* Nesse subcapítulo noto que foi citado várias vezes o grande Couto. Talvez seja a necessidade de lembrar um nome de nossa Medicina que não deve ser olvidado. Não posso nunca esquecer da pergunta que ouvi, há bem seus muitos anos, de interno meu - sextanista - que diante de minha insistência em citar aquele médico perguntou-me - "Mas Doutor Nava, afinal quem era esse Miguel Couto em quem o senhor tanto fala?" isso se passou com um doutorando de 1949 - apenas quinze anos depois da morte desse que, a seu tempo, era o maior médico brasileiro - a própria encarnação da Clínica Médica Brasileira... Preste-se ao menos atenção ao fato de existirem no Rio - uma rua e um hospital com o nome ilustríssimo (Nota de Pedro Nava) (GT, p. 377 , nota).

Já discuti a questão da descoberta do close-up em livro anterior (GT, p. 200).

Assim como para o Falcão de Valadares quero repetir também alguma coisa sobre o Percival de Aquino (GT, p. 297). 
A distinção que se estabelece na obra entre o narrador da primeira parte e aquele da segunda é então marcada no enunciado. Mas quem seria esse nós, ou seja, o narrador 2? Pedro Nava, José Egon, um narrador que não é personagem? Para o crítico literário Joaquim Aguiar, ele se constitui como um narrador de tipo romanesco, de terceira pessoa, que surge como resposta a uma busca por um distanciamento maior em relação à matéria relatada ${ }^{7}$ :

A partir de Galo-das-trevas não teremos mais o mesmo narrador que vinha conduzindo a história, mas um narrador de tipo romanesco. Ele deixa de ser protagonista, cedendo lugar à figura de Egon Barros da Cunha, que seria seu primo. [...] Resumindo o esquema geral do narrador das Memórias é o seguinte: até Galo-das-trevas é grande a proximidade entre a voz que narra e a matéria narrada. A partir desse volume, crescendo o grau de distância entre o narrador e o protagonista, aumenta o terreno da ficção, explicando-se, assim, as investidas romanescas de Nava no final da obra. O narrador transforma-se em personagem secundário que relata e testemunha as aventuras da vida do seu alter ego. É como se a escrita se libertasse do rumo autobiográfico que vinha seguindo, tomando ali o atalho da pura ficção (AGUIAR, 1998, p. 20).

Benveniste (1966) mostra que há apenas duas pessoas do discurso, o eu (aquele que fala) e o tu (com quem se fala), que formam uma categoria oposta à da não-pessoa, o ele (sobre o que se fala, o assunto). A marca de plural e de feminino correspondem à não-pessoa, já que as pessoas do discurso não se pluralizam. Retomando o que diz o linguista francês, Fiorin (1996, p. 60) evidencia que a primeira pessoa e, na maior parte dos casos, a segunda, quando em sua forma plural, são antes pessoas amplificadas que pluralizadas. Logo, o nós não indica a "multiplicação de objetos idênticos, mas a junção de um eu com um não-eu" (FIORIN, 1996, p. 60).

O nós pode representar a soma da primeira pessoa com a segunda $(e u+t u)$, ou da primeira pessoa com a não-pessoa $(e u+e l e)$ ou ainda da primeira com a segunda e a nãopessoa $(e u+t u+e l e)$. Nos três casos, não temos, então, uma somatória de "eus" ou uma multiplicidade de enunciadores. O nós pode ser ainda empregado no lugar do eu - estamos no domínio da embreagem -, é o que se chama plural majestático, de modéstia ou de autor. Conforme explica Fiorin (1996, p. 96), os efeitos resultantes dessa embreagem são diversos. $\mathrm{O}$ eu pode ser amplificado, como em discursos de autoridades, em que se tem o plural majestático. No plural de modéstia, o efeito é de enfraquecimento da subjetividade do $e u$. No caso do plural de autor, utilizado em obras como as científicas, o eu se apresenta como falando em nome de uma comunidade, o que lhe confere certa autoridade e distanciamento maior do que o que temos com o uso da primeira pessoa do singular. Perguntamo-nos, então, a qual desses usos do nós corresponde o que encontramos na segunda parte de Galo-dastrevas.

Numa primeira leitura, a expectativa que se cria, ao final de "Negro", é que a narração continue a ser feita por Pedro Nava ou que seja assumida por José Egon, como um interlocutor que se avoluma no interior do texto. No entanto, ao lermos com mais cuidado a passagem que encerra essa primeira parte, notamos que vamos deparar com mais opacidade:

\footnotetext{
${ }^{7}$ A crítica literária, normalmente, considera narrador em terceira pessoa o narrador que não é personagem, mesmo que se utilize da primeira pessoa do plural. O nós aparece diversas vezes na segunda parte de Galo-dastrevas, mas, em muitas passagens, predomina o apagamento das marcas enunciativas.
}

Disponível em: http://seer.fclar.unesp.br/casa 
Que eu lesse a papelada que ele mandava e onde deixara consignada a estória de sua passagem pela Medicina. E fizesse com ela o que entendesse. Se estivesse uma merda, fogo. Se servisse... Abri e fui tomando conhecimento do que continham as cinco pastas. Eram centenas de folhas manuscritas ora em forma de narrativa, ora de diário, cartas, telegramas, fotografias de família e fotografias obscenas, recortes de jornal, desenho de casas em que morara, notas de suas viagens pelo mundo, às vezes só uma palavra mágica num quadrado de papel, às vezes citações copiadas dos livros que lera, páginas arrancadas deles, recibos, prospectos, recortes de faitsdivers, de convites para missa, participações de falecimento, casamento, nascimento, receitas de remédio e receitas de doces. Havia escritos em papel de carta, de telegrama, margens de jornal, avesso de volantes, papel de cópia, de carta, ofício, almaço. Havia de tudo. Pus em ordem cronológica, depois, nos entreperíodos datados, os fatos mostrados, apontados, flagrados ou comentados, relacionei com estes os documentos fotográficos e de lembranças que eram coevos e fascinado com o que me oferecia a vida do amigo, resolvi transformá-la na narração que se vai ler sob o título de $O$ branco e o marrom. E o que me assombra é que a existência do Egon era carbono, uma espécie de xerox da minha. De tal maneira que a continuação de minhas memórias se tornou inútil diante da publicação que vou promover das do primo-amigo. Com a vantagem de serem mais bem escritas do que eu seria capaz de o fazer - meu parente sempre tendo mostrado especial vocação para as letras, desaproveitada devido a sua eterna desvalorização de si mesmo. Ele e a sua papelada me restituíram um passado tão congênere que sua busca do tempo perdido era a minha. Sua existência foi a minha e a minha continua a ser a de José Egon Barros da Cunha. Quando ele me faz saudades e quero suas novas - fecho os olhos, penso - logo ELE existe (GT, p. 101-102, grifos nossos).

O narrador, identificado a Pedro Nava, aparece como aquele que organizaria a "papelada", supostamente recebida de seu primo, transformando-a em narração; logo ele poderia continuar em seu papel de narrador. Entretanto, ele afirma, ao mesmo tempo, que as memórias de Egon são mais bem escritas do que as suas, motivo que o leva a abrir mão de continuar o relato de sua própria vida para falar da do primo. Assim, não fica claro se ele assumirá ou não a narração da segunda parte da obra; pelo contrário, a passagem citada apenas alimenta a dúvida.

O enunciatário pode pensar que as relações entre o narrador e os atores do narrado, em "O branco e o marrom", serão esclarecedoras, pois aquele que for chamado por um eu (Egon ou Nava), no nível do narrado, poderá ser identificado ao narrador. Entretanto, tanto a Pedro Nava quanto a José Egon se faz referência por meio da terceira pessoa (a nãopessoa: ele). O primeiro a aparecer no texto é Egon, ator do narrado em torno do qual gira a narrativa a partir dessa passagem. Pedro Nava surge algumas páginas adiante:

O Doutor José Egon Barros da Cunha abriu as janelas e o dia sol entrou de roldão (GT, p. 107).

Seus amigos estavam lá dentro, o Ari sentado à escrivaninha e, meio reclinado na giratória de mola, dirigia-se ao Nava montado na única cadeira ali existente, braços cruzados sobre seu encosto. O primeiro era moço de seus trinta anos, dando a impressão de muito magro, porque seu rosto era fino e mais ainda o nariz que se alongava e que era caráter marcante de sua 
fisionomia. [...] O outro era o primo e amigo do Egon, formado com ele há menos de um mês (GT, p. 111).

Durante toda essa parte, o narrador não deixa de fazer menção às anotações deixadas por Egon, de forma a misturar ainda mais as vozes de Nava e do primo:

As notas deixadas pelo Egon referentes a esse período e postas em ordem por Pedro Nava mostram que ele assistiu ao seu espetáculo de lançamento, sempre no Avenida e sempre com os mesmos companheiros (GT, p. 399).

As notas mandadas por Egon a Pedro Nava e donde ele tirou essa narrativa, estão cheias de reflexões do primeiro sobre o assunto. [...] Os cheiros do macho ou da fêmea são viceversamente afrodisíacos. Nesse caso o dos pés deve ter o mesmo papel do dos genitais. Compreenda-se nessa afirmativa do Egon o cheiro normal, não corrompido pela idade, doença e pela prisão nas sapatrancas e nas botinas em que aparece - como as infecções que são favorecidas nas cavidades fechadas (GT, p. 368-369).

Dando um salto para o futuro, suas notas escritas dos anos setenta deixavam consignadas suas longas conversas nesse desacontecido porvir com seu primo Pedro Nava - em que os dois faziam as contas das manhãs em que não tinham vivido - mas em que suas vidas tinham sido literalmente dadas aos outros [...] (GT, p. 258).

Saudosos amigos. Uns perdidos de vista, outros permanecendo afeição fiel da vida inteira, a maioria desaparecida no grande sono... Saudade. Mas alguns deles não são apenas de referência. Nas suas notas, apontamentos, diários - o Egon dedicou-lhes palavras demoradas (GT, p. 279).

Só o vestido merecia uma festa. Nunca o Egon tinha visto, jamais veria nos tempos futuros coisa mais linda. Nas notas tiradas por ele e de onde é tirada a narrativa dessa festa, contava que ao vestido aplicava-se palavra que ele descobrira numa leitura francesa: froufroutantes (GT, p. 250).

Temos, assim, um narrador que usa a primeira pessoa do plural para se referir a si mesmo e que insere os atores do enunciado (Nava e Egon) na narrativa por meio da terceira pessoa. Logo, o enunciatário não tem como ter clareza a respeito de quem está narrando essa segunda parte do livro: se Pedro Nava, se José Egon. O nós pode ser compreendido como um eu+ele (Nava+Egon; ou Egon+Nava), o que parece bem provável devido ao que é dito no final da primeira parte de Galo-das-trevas, ou como um plural de autor - logo, uma embreagem - em que o nós é empregado no lugar do eu (Nava ou Egon) para criar algum distanciamento ou ainda o efeito de amplificação. O nós pode ainda abrigar o $t u$, o narratário, passando a ser formado por eu+ele+tu. Embora esse uso seja menos marcado, há algumas passagens que permitem dizer que o narrador se identifica também ao narratário. Isso ocorre quando ele comenta a própria narração: "Mas é tempo de voltarmos ao Clube do Desterro" (GT, p. 251).

Também não há indícios que permitam definir se os atores do enunciado são discursivizados por meio de uma debreagem enunciva ou de uma embreagem enunciva. Se o narrador é Pedro Nava, logo referir-se a si mesmo na terceira pessoa constitui uma embreagem enunciva do enunciado e referir-se a Egon na terceira pessoa constitui uma debreagem enunciva do enunciado. O mesmo vale para Egon, caso ele seja o narrador. 
Quando Egon se refere a si mesmo na terceira pessoa, está utilizando o recurso da embreagem enunciva; quando se refere a seu primo, Pedro Nava, por meio da terceira pessoa, o recurso da debreagem enunciva.

$\mathrm{O}$ fato de os atores do narrado serem instituídos por meio de marcas enuncivas produz o efeito de objetividade e afastamento do narrador com relação à matéria narrada. $\mathrm{O}$ enunciador também se distancia, já que a "cascata" de identificações parece parcialmente interrompida. Assim, temos para essa segunda parte:

"O branco e o marrom"

- Enunciador: Pedro Nava.

- Narrador 1: Pedro Nava (debreagem enunciativa da enunciação - eu). Ele aparece nas notas, na "capa" do capítulo e em sua organização.

- Narrador 2: Pedro Nava ou José Egon (debreagem enunciativa, o que é mais provável, ou embreagem enunciativa).

- Atores do narrado: Pedro Nava e José Egon (debreagem enunciva do enunciado e embreagem enunciva do enunciado, não necessariamente nessa ordem).

Com isso, em Galo-das-trevas e depois em $O$ círio perfeito, vemos subvertida uma das convenções principais do discurso autobiográfico: a identificação entre enunciador e narrador, narrador e protagonista, e protagonista e enunciador. A sintaxe discursiva, especialmente com relação à actorialização, faz com que o enunciatário não possa afirmar com certeza se essas identificações se realizam nesse discurso ou não. Se o narrador 2 é Egon, produz-se o efeito de identificação entre o narrador 2 e o protagonista Egon, mas fica desfeita a identificação entre esse narrador 2, o narrador 1 e o enunciador. Nesse caso, essas duas obras autobiográficas aproximar-se-iam do romance "ficcional", o que parecia ser o desejo de Pedro Nava, conforme lembra Aguiar (1998, p. 147), já que, se o narrador 2 é Egon, há um narrador que aparece explicitamente como uma criação ficcional e que se diferencia do enunciador. Se o narrador 2 é Pedro Nava, as identidades se mantêm, embora Pedro Nava na segunda parte do livro se torne personagem secundária, o que também gera um estranhamento em relação às coerções genéricas, pois a vida que ele narra é e não é a sua. A ambiguidade produzida na relação entre o narrador 2 e os atores do narrado leva, então, a reler o livro, problematizando a questão das identidades.

$$
\begin{aligned}
& \text { enunciador }=\text { narrador } 1 \\
& \text { narrador } 1=\mathrm{ou} \neq \text { narrador } 2 \\
& \text { narrador } 2=\mathrm{e} \neq \text { atores do narrado } \\
& \text { enunciador }=\mathrm{e} \neq \text { atores do narrado }
\end{aligned}
$$

As crônicas publicadas como anexo no final da obra apenas fortalecem as dúvidas deixadas para o enunciatário. A primeira, "Residências no Rio", que trata de período posterior ao abordado em Galo-das-trevas, constrói as identidades de acordo com o que observamos na obra de Nava até a primeira parte desse quinto volume. Na segunda, "Peixe vivo", o narrador 2 toma a palavra mais uma vez para falar de quando Egon ouviu as letras para "Peixe vivo" criadas por Manuel Bandeira, Vinícius de Moraes, Pedro Nava e outros. 
Quando deixei Oeste Paulista, vim para o Rio, onde cheguei a 10 de março de 1933 (GT, Anexo I, p. 445).

Foi quando minha Mãe mudou-se de Belo Horizonte para o Rio e alugamos o apartamento 302 da Rua Laranjeiras número 382 (GT, Anexo I, p. 452).

Quando o Egon foi ao Tijuco com Gudesteu de Sá Pires, com Fábio Andrada, Pedro Aleixo [...] (GT, Anexo II, p. 453).

A ambiguidade criada pela sintaxe discursiva é mantida na semântica. Se a presença de dois atores do narrado indica tratar-se de duas entidades distintas - Egon e Pedro Nava -, ao longo do livro, o enunciatário encontra inúmeras pistas que apontam para a identificação entre eles. O primeiro elemento que chama a atenção é o nome escolhido para o primo, como vemos em excerto retirado da primeira parte do livro, quando temos o narrador 1:

Pela física ou pela química do mais apelativo, meu parente e amigo é chamado Doutor Egon ou só Egon - para os íntimos. Sempre fomos inseparáveis e sabíamos tudo um do outro. Essa intimidade, esse conhecer das qualidades e defeitos recíprocos muitas vezes nos trazia entediados e doutras chegava a nos dar um nível de aborrecimento resvalando para a hostilidade. Mas não adiantava e terminávamos nos suportando, agüentando, espécie de gostando - na tolerância duma intimidade compulsória que só a morte pode destruir. Pois nossa convivência foi sendo cada vez mais lúcida sobretudo agora, no tempo de nossa vida de velhos em que a introspecção permite a cada, julgamento mais profundo do outro. E temos franquezas luminosas, julgamentos atilados e tão cruéis que fazemos papel de consciência nos momentos mais impecáveis de nossa convivência. Um capítulo sobre esta xifopagia intolerável, essencial, imprescindível - bem poderia trazer na portada as palavras de Chamberlayne que Edgar Allan Poe tomou como epígrafe do seu "William Wilson". Lembram?

\section{Que dirá ela a respeito? Essa CONSCIÊNCIA hedionda,}

Espectro com que tropeço em todos os caminhos?

Mas nem sei se vale a pena penetrar nesses dédalos do sentimento. Basta que se saiba que o Egon e eu somos inseparáveis, mais que amigos, alteregos, mútuos (GT, p. 80).

"Egon" já contém a palavra "ego" dentro de si, sugerindo no nome próprio a ideia de alter ego, ou seja, de um outro, que é ao mesmo tempo um eu ou ainda de um outro centro de personalidade e, por que não, de um outro centro da percepção. Além disso, o narrador, por meio de expressões diferentes, não se cansa de ressaltar que o primo corresponde a um alter ego: classifica a relação deles como uma "xifopagia intolerável, essencial, imprescindível", mostra que um faz o papel de consciência do outro, afirma que são “inseparáveis, mais que amigos, alteregos, mútuos". Na página 102 de Galo-das-trevas, diz que "sua busca do tempo perdido era a minha. Sua existência foi a minha e a minha continua a ser a de José Egon Barros da Cunha" e ainda que a existência de Egon é "carbono", "xerox" da sua. Ao finalizar a primeira parte de Galo-das-trevas, brinca com a máxima de Descartes, "Penso, logo existo", mas substitui a primeira pela terceira pessoa, criando uma 
correspondência entre o eu (Pedro Nava) e o ele (José Egon): "Quando ele me faz saudades e quero suas novas - fecho os olhos, penso - logo ELE existe" (p. 102).

Ao afirmar que sabiam tudo um do outro, que "a introspecção permite a cada, julgamento mais profundo do outro" (p. 80), mostrando que a introspecção, ou seja, o fechamento dentro de si aproxima-o ainda mais de Egon, o narrador retoma ideia apresentada em algumas páginas anteriores. A escritura de suas memórias e a penetração no mais fundo de sua alma correspondem ao mergulho dentro de "outro" homem: Egon. Ou seria de si mesmo?

Conversando comigo, nessa espécie de falar sozinho é que no dia $1^{\circ}$ de fevereiro de 1968 comecei a redigir minhas lembranças. Por elas reduzi ao mínimo minha convivência até com amigos, até com os que mais quero, para não fragmentar e destruir meu tempo, o tempo de que preciso para mim. $\mathrm{E}$ essa fase foi a da punção como num poço, a penetração a fundo de outro homem como eu, outro misantropo e eterno esnobado, vivendo vida de exílio dentro do nosso próprio país. Refiro-me ao que tem sido meu companheiro cada vez mais chegado, meu sósia, primo, amigo de infância, colégio, faculdade, vida, profissão afora (GT, p. 79).

Inclusive a Egon é atribuída a responsabilidade pela continuidade das Memórias, não só porque os manuscritos pertencem a ele, mas porque, antes disso, ele já influenciara Pedro Nava a retomar o trabalho. Segundo o narrador, Egon sugere-lhe que utilize a pena como arma contra aqueles que lhe fizeram mal, ao invés de partir para alguma outra forma de violência: "Use suas armas. Você não está? escrevendo suas memórias. Pois pregue estas pústulas lá, no pelourinho que você lhes armar" (GT, p. 98).

Além disso, na segunda parte do livro, as semelhanças entre Pedro Nava e Egon são colocadas em evidência, pelo narrador 2, diversas vezes. Enquanto Egon é enviado para trabalhar como médico em Santo Antonio do Desterro, que seria sua terra natal, Pedro Nava vai para Juiz de Fora, lugar em que nasceu. O "pseudônimo" escolhido para Juiz de Fora, "Desterro", já anuncia as desventuras do rapaz em sua cidade de origem. Ele não encontra nela o acolhimento desejado. A sociedade é descrita como fechada e muito conservadora. Aqueles que querem prosperar devem curvar-se ante os poderosos e, principalmente, beijar o anel do bispo. O jovem passa antão a ser um desterrado em sua terra. O narrador não deixa de enfatizar o espelhamento entre as vidas dos primos, mostrando que o Desterro poderia muito bem ser Juiz de Fora:

De repente lembrou o primo amigo que estava em Juiz de Fora, Pedro Nava. Recebera carta dele que falava da cidade, dividindo-a em duas: a da direita de quem descia a rua Halfeld - bem-pensante, ultramontana, dos homens do poder e do dinheiro - e a da esquerda - contrincante, irreligiosa - dos intelectuais e da gente de nada que vive de pada e água. Pensando bem ele bem que podia aplicar essa idéia ao Desterro que era cortada em duas partes pela Rua Schimmelfeld (GT, p. 286).

Procedimento semelhante identificamos quando Egon decide chamar sua prima Diva, mãe de Nava, de mãe-prima, confundindo os papéis. Se Dona Diva pode ser sua mãe, Egon poderia também ser seu filho, ou seja, o Nava:

- Prima Diva, acho que dagora em diante vou começar a tratar você do jeito dos filhos da prima Zoleta. Vou chamar também de Mãe. Só que para ficar diferente deles vou conservar o prima. Mãe-prima fica ótimo (GT, p. 325). 
Outra passagem que merece ser comentada diz respeito à autoria do poema " $\mathrm{O}$ defunto", atribuída a Egon nesse momento, mas a Pedro Nava em outros, como no segundo Anexo de Galo-das-trevas: "Foi nesse sótão que mais tarde, a 23 de julho de 1938, dum jato, rejeitei de mim 'O defunto"' (GT, p. 452).

Exatamente nove anos depois, completar-se-ia a gravidez de "O Defunto" e o primo Egon escreveria na noite lancinante da Urca o poema que o habitara desde a infância (GT, p. 370).

Além disso, trata-se de um poema que ganhou certo reconhecimento, foi publicado na antologia organizada por Manuel Bandeira. Logo, o enunciatário identifica esse poema como de Pedro Nava. Não há dúvidas, o enunciador, por meio de uma série de artimanhas discursivas, pretende que o enunciatário reconheça a identidade aproximativa, na semântica discursiva, entre os atores Nava e Egon.

Todos esses recursos para criar a equivalência entre os primos fortalecem a construção do ator José Egon como um alter ego, um ser reveladamente de papel. Enfatizamos o advérbio "reveladamente", pois não queremos fazer a oposição entre Pedro Nava e José Egon (atores do narrado) corresponder a uma oposição do tipo real vs. ficcional. É pertinente, no entanto, mostrar que a própria obra faz com que o enunciatário reconheça o Egon como uma criação discursiva, enquanto para Pedro Nava isso nem sempre ocorre. $\mathrm{O}$ narrador afirma, referindo-se a seu duplo: "Quando ele me faz saudades e quero suas novas fecho os olhos, penso - logo ELE existe" (GT, p. 101-102). Mostra-se assim como aquele que poderia ter inventado o primo-amigo.

A partir de Galo-das-trevas, é intensificado o uso de pseudônimos, algo que já aparece em outros volumes, mas neste até as cidades são batizadas de novo. Apesar disso, o enunciatário das Memórias facilmente reconhece os nomes como sendo pseudônimos, não se trata de enganá-lo. Isso porque o pseudônimo, na obra de Nava, geralmente é construído como algo que não é nem parece o nome "real". É possível para o enunciatário identificar os atores já mencionados nos outros volumes, por meio de sua caracterização, da relação de parentesco e mesmo de alguma semelhança fonética dos nomes: os tios Felisberta e Colatino, por exemplo, são Berta e Palleta. Além disso, geralmente os pseudônimos são criados a partir de nomes pouco usuais e que condensam o julgamento do enunciador a respeito do ator nomeado, principalmente quando a avaliação não é favorável ${ }^{8}$. Os colegas de profissão são os alvos principais da pena afiada do "escritor". É o caso do "Dr. Eutanásio Boamorte" e do "Dr. Sacanagildo Goiaba". Nem sempre o enunciatário será capaz de saber a quem se referem aqueles nomes, mas ele poderá rir um riso mordaz junto com o enunciador que faz assim a crítica desejada. Isso apenas reforça o aparecimento de Egon como máscara sob a qual se esconde Pedro Nava. Poderíamos, então, pensar que na semântica discursiva José Egon Barros da Cunha desempenha papéis tão afins com Pedro Nava que é criado o simulacro da simbiose identitária entre eles.

No entanto, essas observações não são suficientes para compreender os efeitos de sentido produzidos pela existência discursiva de Egon. José Egon é Pedro Nava, mas também não é Pedro Nava. Para construir o ator Egon, são utilizados recursos que criam o

\footnotetext{
8 “Por medida de precaução, os elogiáveis são tratados por seus nomes e os desprezíveis por pseudônimos, todos esquisitos, já contendo em si o traço caricaturesco com que aparecerão: Rosalvo Tranquilino, Cloacário Barata, Josino Rasposo, Alegrino Chuerba, Preposto Concórdia, Variolandopiteco Tucunduva, etc.” (AGUIAR, 1998, p. 149).
} 
efeito de que ele possui uma existência até certo ponto autônoma: Egon existe dentro da obra. Ele tem genealogia própria, cidade natal e até mesmo características que o distinguem de Nava:

Falei dele no Chão de Ferro e no Beira-Mar. É que no Pedro II e Faculdade de Medicina de Belo Horizonte era conhecido como Zegão e que depois de formado passou a ser Doutor José Egon Barros da Cunha, mineiro de Santo Antônio do Desterro - outrora Vila Nova D’El Rey de Santo Antônio do Desterro no Mato Grosso da Minas - nos dias dagora Santo Antônio do Desterro ou só Desterro (GT, p. 79).

Sempre gostei de ver a aptidão dos dois para a Medicina. A vocação servida em cada um por qualidades diferentes. Em você, Nava, pela criatividade e inventividade, em você, Egon, pela capacidade de análise e de crítica (Elogios tecidos por um antigo professor: GT, p. 112).

Quem conquista coração é senhor do corpo. Amado. E viva ele na sua beleza. Era a teoria do Zegão. E quem era? esse Zegão. Nem mais nem menos que meu arquiparente e amigo como os que mais. Arquiparente, por quê? Ele era neto do Desembargador Egon de Barros Palácio e de dona Doralice Barroso Pamplona, ambos primo-irmãos de minha avó paterna. Esse juiz, ao tempo da magistratura móvel, servira na Relação de Ouro Preto onde sua filha Raimundinha de Barros Palácio conhecera o estudante de Farmácia João Elisário Pinto Coelho da Cunha que era primo-irmão de minha avó materna. Foram os pais de José Egon Barros da Cunha, aliás Zé Egon, aliás Zegon (em casa) e aliás Zegão no Externato do Colégio Pedro II. Nós éramos assim primos três vezes e cada um possuía três sangues do outro. Por um capricho genético tínhamos saído cara dum focinho do outro. Era de confundir. [...] Com uma diferença. Ao contrário de mim o Zegão era atirado, audacioso e chegado a elas. Não tinha a minha timidez (CF, p. 227).

Logo, a semântica discursiva constrói a identificação de José Egon e Pedro Nava no modo da ambiguidade, confirmando o que encontramos por meio da análise da sintaxe do discurso. É preciso dizer ainda que essa ambiguidade é constitutiva dessa obra e fundamental para a produção de seu sentido, daí o interesse em explicar por meio de quais mecanismos ela se produz no interior do discurso.

\section{O enunciatário das Memórias}

As observações apresentadas até aqui apontam para a possibilidade de compreender o uso da primeira pessoa do plural por parte do narrador. Essa amplificação do eu em Galo-das-trevas, por meio do emprego do nós, é algo perfeitamente compatível com outros aspectos das Memórias. A obra de Nava incorpora, como memória do enunciador, não apenas suas lembranças de infância e de juventude, mas também aquelas dos antepassados que não conheceu, assim como as histórias dos amigos e dos conhecidos, com suas casas, ruas, e cidades, os objetos que circularam por sua família, os hábitos perdidos no tempo. A fronteira entre o eu e o outro parece, então, diluída, como no emprego desse nós, bastante indefinido, pelo narrador. Seu estilo, que mescla registros e dialetos, também acentua essa tendência à amplificação. Como mostra Arrigucci, não faltam: 
[...] termos regionais e coloquialismos; palavras esquecidas, com o dom de ressuscitar o passado de que um dia foram parte; vocábulos cultos e preciosos, nomes exóticos que deixam sabor na boca; palavrões em quantidade; estrangeirismos, sobretudo galicismos abundantíssimos; tecnicismos da linguagem médica e científica em geral; neologismos; tesouros dos clássicos portugueses; uma verdadeira avalanche de nomes próprios, muitas vezes já esvaziados das pessoas e lugares que os habitaram, com a rara e surpreendente poesia de seu puro som; latinismos e todo o baú de virtualidades da língua, atualizadas, arejadas, encarnadas concretamente e postas a caminhar na frase aberta e inclusiva sob a luz do presente (1987, p. 72-73).

A criação de um narrador que fala na primeira pessoa do plural e ainda o uso do sistema enuncivo para referir-se aos atores do narrado possuem também outros efeitos. Se podemos dizer que a escritura autobiográfica permite o surgimento de um $e u$, de um éthos, que se constitui ao longo do processo da escrita, Egon parece materializar no texto uma parte desse $e u$. Ele aparece em Chão de ferro e vai ganhando espaço até tornar-se o protagonista e suposto narrador das Memórias, como se o próprio Nava se tornasse esse outro, ao qual se identifica e do qual se diferencia ao mesmo tempo.

Maingueneau (2005) estabelece uma diferenciação gradual entre o éthos dito e o éthos mostrado. O primeiro é construído a partir daquilo que o enunciador "fala" de si mesmo, de referências diretas e explícitas; o segundo, que na verdade estaria mais próximo do que vem sendo tratado como éthos na semiótica (DISCINI, 2003), é reconstituído a partir de um modo de dizer, de recorrências textuais e discursivas. Podemos depreender o alter ego como uma concretização, feita por meio do ator do enunciado, do éthos dito: a parte que o enunciador quer mostrar de si mesmo, mas sem ter que se preocupar com as imposições sociais de modéstia que geralmente incidem sobre aqueles que falam de si. As estratégias empregadas para a criação do alter ego, essa espécie de éthos dito, contribuem ainda para a projeção do éthos mostrado.

Além de corroborar a tendência à amplificação e de participar jogo de projeção dos éthe, os recursos mencionados possuem outros papéis e podem ser examinados tendo em vista o impacto sensível que a obra provoca em seu enunciatário. Conforme o narrado parece aproximar-se do presente da narração, ocorrem algumas mudanças: a história passa a ser contada pelo narrador 2, apresentado por meio de marcas enunciativas de pessoa (nós); Pedro Nava, ator do narrado, perde seu lugar de protagonista e passa a ser discursivizado por meio do sistema enuncivo; Egon torna-se o protagonista, ainda que apresentado por meio de marcas enuncivas de pessoa. $O$ efeito é não só de embaralhamento na semântica (em relação à construção dos atores) e na sintaxe (em relação à instalação de pessoas no enunciado), mas também de distanciamento dos fatos narrados em relação à enunciação. Além disso, embora muitas indicações permitam criar a identificação entre Egon, o novo protagonista das Memórias, e o enunciador, a discursivização da pessoa, feita de forma labiríntica, distancia um do outro.

Afirmar que Egon é Nava, sem qualquer problematização, seria desconsiderar a própria obra que trabalha com a incompletude, a incerteza, questionando a concepção de discurso autobiográfico como reprodução do real. A obra autobiográfica é, assim, apresentada como criação. Daí talvez se possa extrair alguma verdade dessas páginas. Ao modo do clichê, José Egon "afirma" que "A vida é um romance sem enredo (De um manuscrito de José Egon Barros da Cunha)" (GT, p. 103), aproximando literatura e vida. A 
existência de Egon pode, portanto, ser entendida como uma forma de discutir o estatuto do próprio discurso autobiográfico, algo que o narrador já vinha fazendo ao longo da obra.

A aparição de Egon, com todas as implicações já comentadas, poderia apontar, então, para uma estetização maior do passado, no sentido de que a obra poderia se desprender completamente dos procedimentos de criação do efeito referencial, que insere enunciador e enunciatário num discurso social partilhado, do qual fazem parte lugares, tempos e pessoas reconhecíveis. Entretanto, isso não se realiza, o que vai ao encontro das palavras de Aguiar:

\begin{abstract}
Afastando-se para a terceira pessoa, o escritor buscava evidenciar o perfil ficcional de suas Memórias. Ocorre, entretanto, que a providência tomada não faz subir o nível estético dos livros. Ao contrário, como tem observado a crítica, a qualidade da obra tende a cair nos últimos dois volumes (1998, p. 147).
\end{abstract}

O narrador se distancia da narração, por meio de tempos, de espaços e, na segunda parte desse quinto volume, também de pessoas, discursivizados no narrado a partir do sistema enuncivo. Esse recurso cria o efeito de objetividade e de distanciamento, afastando o enunciador da matéria narrada e também o enunciatário. É preciso dizer que a aparição de Egon leva às últimas consequências a diferença, já dada pelo sistema temporal, entre o $e u$ do narrado e o eu da narração, aumentando a cisão vivida pelo narrado1/enunciador e o mundo rememorado; ele não pode mais reviver o passado pela lembrança.

Outras estratégias linguísticas e discursivas poderiam ser empregadas para reverter essa cisão, mas não é o que se manifesta. Comparando os momentos em que o passado ressurge em Baú de ossos e Galo-das-trevas, por exemplo, vemos que há uma queda no impacto sentido pelo leitor, tomado sempre como entidade pressuposta. Apenas para ilustrar nossas afirmações reproduzimos a seguir um trecho exemplar de Baú de ossos, em que o narrador, diante da casa em que morara, vê-se tomado pelas lembranças da infância. A sequência de sintagmas, com rarefação do elo explícito da conjunção coordenativa, produz para o sujeito da enunciação (enunciador e enunciatário) o mesmo impacto e velocidade sentidos pelo ator do enunciado diante do velho sobrado:

Foi aquele tumultuar, aquele entrechoque arbitrário de diversidades se conjuntando em coisa única: consubstanciaram-se as ferragens caprichosas da frente, os dois lances da escada de pedra, bicos de gás da sala de jantar, as quatro figuras de louça da varanda (Primavera, Verão, Outono, Inverno), um velho oratório, o baú cheio de ossos, o gradil prateado, o barulho da caixa d'água, o retrato da prima morta, o forro de couro macio das espreguiçadeiras, o piano preto e o cascalhar de suas notas e escalas ao meio-dia, os quartos, os ângulos do telhado, os rendados de madeira da guarnição do frontispício, silêncios, risos, tinidos de talher, frescuras de moringas de barro, vozes defuntas em conversas outrora, murmúrio noturno das ondas do rio Comprido, avencas e begônias, minha Mãe convalescendo, meu Pai chegando, minhas tias, as primas - tudo, tudo, todos, todos se reencarnando num presente repentino; outra vez palpável, visível, magmático, coeso, espesso e concentrado - tal a súbita franja feita por limalha de ferro atraída pela força dum ímã (BO, p. 290).

A significativa redução de emprego das conjunções conduz, então, a uma leitura célere. A estrutura que se repete, sem encaminhar-se para qualquer resolução, gera a sensação de acúmulo, mesmo tipo de acúmulo que observamos na duplicação dos pronomes 
indefinidos "tudo" e "todo", que já se apresentam como num grau de força máxima. É como se tudo o que fosse lembrado tivesse que ocupar o mesmo ponto espaçotemporal, a mesma pequena fratura aberta no presente do narrador. A ênfase dada aos sentidos, especialmente à visão, coloca enunciador e enunciatário em meio àquele "entrechoque arbitrário de diversidades". O narrador fala do prateado do gradil, do barulho da caixa d'água, do pretume do piano e do som de suas notas, da maciez do couro das espreguiçadeiras, etc. Não é possível para o enunciatário formar uma imagem clara da casa, pois ela é dada a ver quase que apenas por aspectos sensoriais, de forma metonímica. A lembrança interpela os sentidos, os afetos, não fornecendo contornos nítidos; por enquanto, é pura intensidade ${ }^{9}$. A aparição de figuras humanas é feita por verbos no gerúndio ("minha Mãe convalescendo, meu Pai chegando"), incialmente sua presença é indicada apenas pelos sons que produzem ("risos", "tinidos de talher", etc). O uso do gerúndio, somado à falta de localização temporal, produz para o sujeito da enunciação o efeito de que a cena ocorre fora do tempo.

Assim, nesse fragmento, a sintaxe textual "desregrada", a ênfase em aspectos sensoriais e afetivos, a ausência de topônimos, antropônimos e cronônimos, entre outros recursos, distanciam o discurso de procedimentos referenciais e, ao mesmo tempo, fazem com que o momento de rememoração surpreenda não apenas o narrador, invadido pelas reminiscências, mas também o enunciatário, que se vê imerso, sem preparação, nessa cena bastante sensorial, cuja inteligibilidade é reduzida. No geral, não é isso que encontramos em Galo-das-trevas:

E ele marchava na claridade que despencava em catadupas do sol de assombro, retomava a impressão desértica que lhe sugeriam os baldios e os muros mortos daquela ponta de rua. Tinha a impressão desértica que lhe sugeriam os baldios e os muros mortos daquela ponta de rua. Tinha a impressão de estar num areal, numa estepe, num pampa infindável onde o dia jamais teria fim com aquele sol estacado ao gesto mágico dum Josué. O céu era outro descampado imenso, imóvel da parada do astro e da falta dos ventos - duro e mineral - calota de turquesa inexorável (GT, p. 322).

$\mathrm{Na}$ passagem mencionada, vemos que Egon recebe o passado como algo intenso, que abre uma clareira no cotidiano. Ele sente-se inclusive angustiado antes de pisar as ruas percorridas na infância, prenunciando a possível revivescência. Já para o enunciatário muito é explicado, as frases aparecem completas, bem encadeadas, a leitura é mais lenta. Não há espanto. Ocorre, assim, de um livro para o outro uma perda na intensidade com relação à enunciação.

Como mostramos, seria pertinente levantar a hipótese de que a substituição de um narrador que usa a primeira pessoa do singular (narrador 1, aquele que aparece nas Memórias até o início do de Galo-das-trevas) pelo narrador que fala na primeira pessoa do plural ou que apaga as marcas enunciativas em muitos momentos (narrador 2, aquele que aparece nas Memórias a partir da segunda parte de Galo-das-trevas) e ainda a substituição do sistema enunciativo pelo enuncivo para referir-se aos atores do narrado criariam uma estetização maior da obra, visto que os recursos predominantes em Galo-das-trevas são aqueles que caracterizam as obras que buscam produzir efeitos de ficcionalização, próprios da literatura. Não é, porém, o que pudemos observar em nossa breve análise. O exame centrado, principalmente, na textualização revelou que em Galo-das-trevas a linguagem, se comparada

\footnotetext{
${ }^{9}$ Recuperamos nessa análise a noção de intensidade proposta por Zilberberg (2006), como eixo do sensível, dos afetos, e que tem como noção correlata a extensidade, eixo do inteligível.
}

Disponível em: http://seer.fclar.unesp.br/casa 
àquela empregada em Baú de ossos, tende a afastar-se, ainda que pouco, da poesia, o que resulta na diminuição do impacto sensível experimentado pelo enunciatário. Ficcionalização e estetização parecem não caminhar obrigatoriamente na mesma direção, possuem autonomia.

$\mathrm{O}$ questionamento dos efeitos de identidade próprios ao discurso autobiográfico produz, portanto, a partir da segunda parte de Galo-das-trevas, não somente o distanciamento entre narrador e protagonista, mas também entre sujeito da enunciação (enunciador e enunciatário) e protagonista. Daí o passado ser afastado do enunciatário, agora convidado a participar da obra de outro modo.

\section{REFERÊNCIAS}

AGUIAR, J. A. de. Espaços da memória. Um estudo sobre Pedro Nava. São Paulo: Edusp, 1988.

ALENCAR, J. de. Como e por que sou romancista. Salvador: Progresso, 1955.

ARRIGUCCI Jr, D. "Móbile da memória". In: Enigma e comentário. São Paulo:

Companhia das Letras, 1987, p. 67-111.

BENVENISTE, E. Problémes de linguistique générale. Paris: Gallimard, 1966, vol. 1.

CASTELO, J. A. A literatura brasileira. Origens e unidade. São Paulo: Edusp, 1999, v. 2.

DISCINI, N. O estilo nos textos. São Paulo: Contexto, 2003.

FÁVERO, A. H. Aspectos do memorialismo brasileiro. (Tese de doutorado em Literatura Brasileira) Faculdade de Filosofia, Letras e Ciências Humanas, Universidade de São Paulo, São Paulo, 1999.

FIORIN, J. L. As astúcias da enunciação. São Paulo: Ática, 1996.

GENETTE, G. Fiction et diction. Paris: Seuil, 1991.

GREIMAS, A. J; COURTÉS, J. Dicionário de Semiótica. Trad. Alceu Dias Lima et alii. São Paulo: Cultrix, 2008.

LEJEUNE, P. Le pacte autobiographique. Paris: Seuil, 1996.

. Sgnes de vie. Le pacte autobiographique 2. Paris: Seuil, 2005.

MAINGUENEAU, D. "Ethos, cenografia, incorporação". In: AMOSSY, R. (Org.). Imagens de si no discurso: a construção do ethos. São Paulo: Contexto, 2005, p. 69-92.

NAVA, P. Baú de ossos. São Paulo: Ateliê, 2000a.

Balão cativo. São Paulo: Ateliê, 2000b.

. Chão de ferro. São Paulo: Ateliê, 2001.

Galo-das-trevas. São Paulo: Ateliê, 2003b.

O círio perfeito. São Paulo: Ateliê, 2004.

Cera das almas. São Paulo: Ateliê, 2006.

PARRET, H. Le sublime du quotidien. Paris-Amesterdam-Philadelphia: Hadès- Benjamins, 1988.

ROUSSEAU, J-J. Les confessions de Jean-Jacques Rousseau. Paris: Pleiade, 1933.

STAROBINSKI, J. Le style de l'autobiographie. Poétique. Paris: Seuil, 1970, v. 3, p. $257-$ 265.

ZILBERBERG, C. Eléments de grammaire tensive. Limoges: Pulim, 2006.

Recebido em: $15 / 08 / 12$

Aprovado em: 04/11/12 